\title{
Thematic Symposium: Accounting Ethics and Regulation: SOX 15 Years Later
}

\author{
Sally Gunz ${ }^{1} \cdot$ Linda Thorne ${ }^{2}$
}

Received: 26 February 2018 / Accepted: 2 March 2018 / Published online: 27 March 2018

๑) Springer Science+Business Media B.V., part of Springer Nature 2018

The Sarbanes-Oxley Act (SOX) of 2002 is widely argued to be the most important piece of securities legislation since the Securities Act, 1933 and the Securities and Exchange Commission was created in 1934. Its substance was replicated in many other jurisdictions. SOX was a response to widespread ethical and legal failures in corporate US that went beyond internal corruption to include complicity on the part of the traditional watch dogs of the financial markets, government agencies, the auditors and the regulators. At the 10th anniversary of SOX, Senator Sarbanes commented:

My hope is that the Act becomes so much a part of the way business is done in this country; so much a part of establishing the standards, that it is not seen as something separate and apart. It really becomes part of the very structure of the business world. And what comes out of that, of course, are higher standards, more ethical behavior and to the benefit of everyone.

\section{The Objectives of SOX}

SOX had the primary objective of curbing fraud and encouraging ethical behavior in private enterprises by company employees, and most notably by executives and auditors of the corporation. SOX sought to protect investors through strengthening the corporate governance and increasing the transparency and reliability of financial disclosures. Specifically, SOX increased whistleblowing protection and compliance monitoring through the creation of the Public Company Accounting Oversight Board (PCAOB) ending

Sally Gunz

sgunz@uwaterloo.ca

1 School of Accounting and Finance, University of Waterloo, Waterloo, Canada

2 Schulich School of Business, York University, Toronto, Canada over 100 years of self-regulation. SOX required executives to attest to the accuracy of financial disclosures through the personal certification of corporate financial statements, and increased the penalties for corporate and executive malfeasance. SOX required companies to establish and report on a system of internal controls over financial reporting. It mandated independent audit committees and required issuers to disclose whether a "financial expert" is on the audit committee. SOX required companies to disclose off-balance sheet arrangements in financial reports, an obvious acknowledgement of the Enron failure. Finally, in terms of the accounting firms that provide audit and other functions, SOX prohibited any one firm from performing auditing and consulting services for the same company.

Approximately 44 other countries quickly followed the lead of the US and passed similar legislation designed to impose governance reform with the end objective of encouraging transparent financial reporting and to oversee the accounting profession, and ultimately, to end financial fraud and market failure, (Young 2006; Harris 2012).

SOX was passed quickly and had ambitious goals. Fifteen years later the effect and the effectiveness of SOX is still being debated. In today's changed climate where repeal of much of the Dodds-Frank Act (2010) is a distinct possibility, the need to examine and understand SOX and other similar legislation has never been more important.

\section{The Impact of SOX: What We Know}

What do we know about the impact of SOX? Many researchers have addressed this question through empirical observations of the economic impact of SOX on the stock markets, companies and audit firms. This body of work showed that immediately upon the imposition of SOX, the financial markets reacted negatively, most likely as a result of the costs that were expected to be imposed by SOX on firms through additional audit and governance requirements (Zhang 2007). 
These increased costs were in fact borne out. SOX has been estimated by the SEC to result in an additional US $\$ 91,000$ cost per company and by the Financial Executives Institute to be 48 times the SEC estimate (McLuhan 2007). ${ }^{1}$ Empirical evidence substantiates that audit fees alone rose approximately $74 \%$ in the post-SOX period, and even more where Big 4 audit firms were used (Ghosh and Pawlewicz 2009).

As anticipated, SOX has increased the demand for and workload of outside directors, as boards are now larger, more independent, and required to meet more often (Linck et al. 2008a, b). Internal control requirements have increased as have financial and information disclosure requirements (Gordon et al. 2006). Fewer deficient audit quality lawsuits have been filed and the obvious inference is that this reflects improved quality (Harris 2012). Immediately following the implementation of SOX the number of financial restatements increased dramatically (Turner and Weirich 2006; Chen et al. 2014), but this trend reversed itself as early as 2005 (Harris 2012). Empirical research (Palmrose et al. 2004; Chen et al. 2013) shows that restatements result in negative market reactions and increase the cost of firms' capital (Hribar and Jenkins 2004).

Despite an extensive body of research on the impact of SOX in general, 15 years later the essential question of whether SOX has reduced unethical actions on the part of executives and auditors remains largely unanswered. Very little research has considered this particular issue which is somewhat surprising since executives and auditors are the very individuals who were supposed to be the target of the legislation. It therefore is appropriate to consider now whether SOX was effective in promoting more ethical behavior in reporting in enterprises and by corporate executives and auditors and this is the focus of this Thematic Symposium.

\section{SOX and Its Implications for Ethical Behavior in Organizations}

While existing research mainly focused on the economic consequences of SOX, our forum specifically considers the question of whether SOX has promoted ethical behavior and transparent reporting within corporations and their auditors. We present three papers that first appeared in draft format at a Symposium conducted by the Centre for Accounting Ethics, University of Waterloo, in Toronto, April 2017. Two investigate the related areas of financial statements

\footnotetext{
${ }^{1}$ Furthermore, empirical research shows that the costs of Sox are disproportionately felt by smaller firms (Holmstrom and Kaplan 2003), which has led to some exemptions being granted from securities regulation based on size of corporation (Gao et al. 2009a, b).
}

and clawbacks, both of which are requirements of SOX that are of particular relevance in terms of examining the influence of SOX on the ethicality of executives' behavior in organizations. SOX Section 404 addresses restatements and Section 304 requires that executive compensation be clawed back when restatements occur. The final paper in this Thematic Symposium considers the impact of SOX on nonprofits' financial reporting and ethical climate.

SOX Section 404 requires the CEO and the CFO to opine on whether the internal controls of the firm are effective and whether a material misstatement of the financial statements exists. Section 404 makes executives' responsible both for the internal controls and for transparent and honest financial reporting. If the financial statements contain a material misstatement that later requires restatement, then this may have occurred either because management itself failed to ensure that internal controls were adequate and by so doing, failed to detect the mistake, or it failed to disclose the misstatement itself. Perhaps, due to the increased scrutiny of financial statements and the responsibility of executives resulting from SOX Section 404, SOX initially resulted in an increase in the number of restatements of organizations' financial statements. These changes may have undermined trust in transparency and in the audit function, which at first glance appears to be counterintuitive to the objectives of SOX.

Our first paper by Cianci Clor-Proell, and Kaplan considers whether restatements increase or undermine the trust that investors have in the executive team. In particular, Cianci et al. (2018) examine the joint effects of pre-restatement managerial reputation and the announcement of managerial corrective actions in response to a restatement. In so doing, they attempt to tease apart whether investors' responses to restatements reflect an improvement or a deterioration in the trust of managers. Their results show that, in fact, the corrective action that the restatement represented resulted in an increase in investors' trust and thereby in greater investment and CEO retention. Thus, their findings suggest that the SOX requirement for corrective restatement is viewed positively by investors and should consequently offset, at least to some extent, the negative economic consequences associated with issuing a restatement.

SOX Section 304 (Forfeiture of Certain Bonuses and Profits), the clawback provision, allows the SEC to recover compensation paid to CEOs and CFOs in the 12 months following the restatement of financial statements. The purpose of the provision was to increase executives' accountability for less than honest reporting, create a positive ethical climate, and encourage transparent reporting by the firm. The SOX provisions were reinforced by the Dodd-Frank Act, 2010. Surprisingly, Pyzoha (2015) presented empirical evidence that suggests that clawbacks may have the opposite effect to that intended. By effectively imposing a financial penalty on executives for financial restatement, 
the likelihood of financial restatements is inhibited. Accordingly, it is not clear whether the reduction in number of restatements post-2005 was a result of increases in the honesty in the initial reporting by companies or due to the threat of clawback provisions inhibiting executives and auditors from proposing and implementing financial restatements. The Cianci et al. (2018) paper provides more and useful insight into the effectiveness of clawbacks and restatements.

The second paper in this Thematic Symposium, Brink et al. (2018) investigates the effect of clawbacks on auditors through a series of three experiments. They show, perhaps contrary to their own initial expectations, that the presence of clawbacks does not inhibit auditors' risk of material misstatement nor their willingness to propose restatements. Instead, and favorably, the results suggest that SOX has resulted in a more positive ethical climate and that the decrease in the number of restatements may be due to an increase in financial transparency and stronger internal controls in the post-SOX era.

The third paper in this series addresses a large hole in our understanding of the impact of SOX, namely the effect of SOX on over 1 million nonprofit organizations. Particular provisions of SOX apply to all private organizations in the USA including not-for-profits which have devoted considerable effort to implementing SOX mandated provisions to their operations (Nezhina and Brudney 2012). Consequently, SOX required policies have influenced the operations of nonprofits, and, as with the for profit sector, at considerable additional cost including higher audit and administrative costs (Nezhina and Brudney 2012).

Saxton and Neely (2018) examine the impact of SOX on the nonprofit sector by considering three key policies that are explicitly applicable to charities: (1) conflict-of-interest policies, (2) records retention policies, and (3) whistleblower policies. They argue that a decline in the reporting of lapses in these three areas would suggest that the ethical climate of charities in the nonprofit sector is improving. An empirical examination of lapses as reported by a large third-party ratings agency, Charity Navigator, suggests that there is a decline in lapses in all three areas. These findings suggest that SOX has indeed improved the ethical climate and transparency in nonprofit organizations.

\section{Conclusion}

The three investigations described in this Thematic Symposium considered and appeared to demonstrate that by strengthening corporate governance and increasing the transparency of financial disclosures required of enterprises, SOX has resulted in executives acting at least somewhat more ethically. Furthermore, all three papers consider the effect of SOX beyond that of pure economic impact on organizations themselves by focusing on how SOX affected the ethical behavior of investors and auditors, and the overall ethical culture in organizations. The three studies suggest that the goals of increasing transparency and trust in financial reporting appear to have been met, as trust on the part of investors has increased, and ethical climate in organizations has improved. If indeed SOX has resulted in a positive change on organizations, the question still remains, is the increased cost that SOX imposes on organization economically worth the price? This remains to be seen. The detractors of SOX will continue to argue the costs of SOX are too high, but the three studies included in the volume suggest that the effectiveness of SOX in terms of increasing investors' trust in the transparency of financial statement reporting and in encouraging ethical behavior and ethical climate in organizations is undisputed.

We have complied with the ethical standards of Journal of Business Ethics, and we have not used human or other participants in this article.

\section{References}

Brink, W. D., Grenier, J. H., Pyzoha, J. S., \& Reffett, A. (2018). The effects of clawbacks on Auditors' propensity to propose restatements and risk assessments. Journal of Business Ethics. https:// doi.org/10.1007/s10551-018-3846-x.

Chen, K. Y., Elder, R. J., \& Hung, S. (2014). Do post-restatement firms care about financial credibility? Evidence from the pre-and post-SOX eras. Journal of Accounting and Public Policy, 33(2), $107-126$.

Chen, X., Cheng, Q., \& Lo, A. K. (2013). Is the decline in the information content of earnings following restatements short-lived? The Accounting Review, 89(1), 177-207.

Cianci, A. M., Clor-Proell, S. M., \& Kaplan, S. E. (2018). How do investors respond to restatements? Repairing trust through managerial reputation and the announcement of corrective actions. Journal of Business Ethics. https://doi.org/10.1007/s1055 1-018-3844-z.

Gao, F., Wu, J. S., \& Zimmerman, J. (2009a). Unintended consequences of granting small firms exemptions from securities regulation: Evidence from the Sarbanes-Oxley act. Journal of Accounting Research, 47(2), 459-506.

Gao, F., Wu, J. S., \& Zimmerman, J. (2009b). Unintended consequences of granting small firms exemptions from securities regulation: Evidence from the Sarbanes-Oxley act. Journal of Accounting Research, 47(2), 459-506.

Ghosh, A., \& Pawlewicz, R. (2009). The impact of regulation on auditor fees: Evidence from the Sarbanes-Oxley Act. Auditing: A Journal of Practice \& Theory, 28(2), 171-197.

Gordon, L. A., Loeb, M. P., Lucyshyn, W., \& Sohail, T. (2006). The impact of the Sarbanes-Oxley Act on the corporate disclosures of information security activities. Journal of Accounting and Public Policy, 25(5), 503-530.

Harris, S. (2012). Remarks on the Sarbanes-Oxley Act of 2002: Ten Years Later Sept. 24, 2012 Steven B. Harris, Board Member.

Holmstrom, B., \& Kaplan, S. N. (2003). The state of US corporate governance: What's right and what's wrong? Journal of Applied Corporate Finance, 15(3), 8-20. 
Hribar, P., \& Jenkins, N. T. (2004). The effect of accounting restatements on earnings revisions and the estimated cost of capital. Review of Accounting Studies, 9(2), 337-356.

Linck, J. S., Netter, J. M., \& Yang, T. (2008a). The determinants of board structure. Journal of Financial Economics, 87(2), 308-328.

Linck, J. S., Netter, J. M., \& Yang, T. (2008b). The effects and unintended consequences of the Sarbanes-Oxley Act on the supply and demand for directors. The Review of Financial Studies, 22(8), $3287-3328$.

McLuhan, S. (2007). One issue, two voices. Washington: Woodrow Wilson International Center for Scholars.

Nezhina, T. G., \& Brudney, J. L. (2012). Unintended? The effects of adoption of the Sarbanes-Oxley Act on nonprofit organizations. Nonprofit Management and Leadership, 22(3), 321-346.

Palmrose, Z. V., Richardson, V. J., \& Scholz, S. (2004). Determinants of market reactions to restatement announcements. Journal of Accounting and Economics, 37(1), 59-89.
Pyzoha, J. S. (2015). Why do restatements decrease in a clawback environment? An investigation into financial reporting executives' decision-making during the restatement process. The Accounting Review, 90(6), 2515-2536.

Saxton, G. D., \& Neely, D. G. (2018). The relationship between sarbanes-oxley policies and donor advisories in nonprofit organizations. Journal of Business Ethics. https://doi.org/10.1007/s1055 1-018-3843-0.

Turner, L. E., \& Weirich, T. R. (2006). A closer look at financial statement restatements analyzing the reasons behind the trend. $C P A$ Journal, 76(12), 12.

Young, M. (2006). Accounting irregularities and financial fraud, 3rd edn.

Zhang, I. X. (2007). Economic consequences of the Sarbanes-Oxley Act of 2002. Journal of Accounting and Economics, 44(1), 74-115. 